\title{
POTENTIATION OF AMINO ACID ANTAGONISTS ON ANTIVIRAL EFFECT OF GUANIDINE
}

\author{
TAKEO UEDA,* SHIGESHI TOYOSHIMA, ATSUSHI TAKADA and \\ YOSHIKO SETO \\ Pharmaceutical Institute, School of Medicine, Keio University, \\ Tokyo, Japan
}

(Received for publication September 2, 1963)

It was found by our group(1) that commoner guanidine salts such as nitrate, chloride, sulfate, carbonate and phosphate showed remarkably inhibitory effect on the intracellular multiplication of both viruses of polio and measles. This effect of guanidine salts, however, is considered somewhat weak to utilize them as antiviral drugs. As the approach to an antiviral agent, the authors conceived an idea to potentiate the effect of guanidine in addition of amino acid antagonists and their related.

Ackermann et al.(2) reported that some of amino acid antagonists such as canavanine, ethionine, methionine homologs etc. inhibited the intracellular multiplication of polio virus in tissue culture.

On the contrary, Syverton et al.(3) clarified that the effect of those antagonists was caused by the toxic action on the respiration of host cells and they were completely ineffective on the virus, if the nontoxic dose of each of them on the cellrespiration was employed for the experiment of tissue culture.

The authors ascertained that those antagonists did not show any inhibitory effect on polio virus with nontoxic dose, and found that ethionine potentiated the effect of guanidine on the virus in tissue culture and animal experiments.

This finding is of interest to be useful as a clue for searching for an antiviral drug.

This report is concerned with the antiviral effect of salts of guanidine with amino acid antagonists and their related.

\section{INVESTIGATION IN TISSUE CULTURE SYSTEM}

\section{MATERIALS AND METHOD}

Virus: Mahoney strain of polio virus was used throughout this investigation.

\footnotetext{
* Professor of Pharmaceutical Institute.
} 
Host Cells: HeLa cells were employed.

Madia: For the growth medium, the YLA medium supplemented with $15 \%$ bovine serum was used, and for the maintenance medium, the YLA medium supplemented with $5 \%$ bovine serum.

Culture of cells and cultivation of viral material: The experiments were carried out at $37^{\circ}$ by using stationary cell-culture method, and the cultivation of the Mahoney strain also was carried out by using the same method.

The experimental procedures in details will be described in the respective separated sections.

\section{EXPERIMENTAL RESULTS}

1) Antiviral Effect of Amino Acid Antagonists and their Salts with Guanidine.

For the test, canavanine, norleucine, ethionine and their salts with guanidine were used.

First of all, the toxicity of the amino acid antagonists on HeLa cells was determined. Each of various dilutions of each of these amino acid antagonists was added into tubes in which the monosheet of HeLa cells had been established, and then these tubes were incubated at $37^{\circ}$ for seven days. After the microscopic observation, the maximum nontoxic concentration of each of the amino acid antagonists was determined. The maximum nontoxic doses of canavanine, norleucine and ethionine were $10^{-5}, 10^{-3}$ and $10^{-3}$ mole respectively.

At next, the inhibitory effect of the tested compounds was observed as follows. Each of dilutions of these compounds was added into tubes in which the

Table 1 .

\begin{tabular}{lccc}
\hline \multicolumn{1}{c}{ Compound (Mole) } & $\begin{array}{c}\text { Result }\left(\mathrm{TCID}_{50} \text { per } 0.1 \mathrm{ml}\right) \\
\text { Treated Group }\end{array}$ & Control Group & Effect \\
\hline Canavanine $\left(10^{-5} \mathrm{M}\right)$ & $10^{-6.5}$ & $10^{-6.5}$ & - \\
Norleucine $\left(10^{-3} \mathrm{M}\right)$ & $10^{-6.5}$ & $10^{-6.5}$ & - \\
Ethionine $\left(10^{-3} \mathrm{M}\right)$ & $10^{-6.5}$ & $10^{-6.5}$ & - \\
Guanidine Nitrate $\left(2 \times 10^{-4} \mathrm{M}\right)$ & $10^{-6.5}$ & $10^{-6.5}$ & - \\
Guanidium Canavaninate $\left(10^{-5} \mathrm{M}\right)$ & $10^{-6.5}$ & $10^{-6.5}$ & - \\
Guanidium Norleucinate $\left(2 \times 10^{-4} \mathrm{M}\right)$ & $10^{-8.5}$ & $10^{-6.5}$ & - \\
Guanidium Ethionate $\left(2 \times 10^{-4} \mathrm{M}\right)$ & $10^{-4.5}$ & $10^{-6.5}$ & + \\
Guanidium Nitrate $\left(2 \times 10^{-4} \mathrm{M}\right)$ & $10^{-4.5}$ & $10^{-6.5}$ & + \\
$\quad$ +Ethionine $\left(8 \times 10^{-4} \mathrm{M}\right)$ & & & \\
\hline
\end{tabular}


monosheet of the HeLa cells had been established and soon later, the various dilutions of Mahoney strain of polio virus was inoculated into these tubes. Then, these tubes were incubated at $37^{\circ}$ for seven days. After the daily microscopic observation, the TCID 50 of the treated and the control groups was evaluated.

The experimental results are shown in Table 1. As can be seen from the table, only guanidium ethionate showed an inhibitory effect under the above experimental condition, among the tested compound.

2) Inhibitory Effect of Compounds of $a$-Amino- $\gamma$-alkylthiobutyrate*

To investigate the relationship between the chemical structure and the inhibitory effect of $\alpha$-amino- $\gamma$-alkylthiobutyrate, the effect of these compounds was examined in the system of Mahoney strain and HeLa cells. The free acids employed for this investigation were as follows: n-isopropyl-, n-butyl-, isobutyl-, n-pentyl-, isopentyl- and n-hexylthio- $\alpha$-aminobutyric acids.

The toxity of these compounds on HeLa cells was determined by using the same method to that described above. The maximum nontoxic concentrations are shown in Table 2.

Table 2.

\begin{tabular}{cc}
\hline $\begin{array}{c}\text { Compound } \\
\text { R-S- } \mathrm{CH}_{2}-\mathrm{CH}_{2}-\mathrm{CH}\left(\mathrm{NH}_{2}\right) \mathrm{COOH}\end{array}$ & $\begin{array}{c}\text { Maximum nontoxic concentration } \\
\mathrm{R}\end{array}$ \\
n-Isopropyl & $10^{-3}$ \\
n-Butyl & $2 \times 10^{-4}$ \\
Iso-butyl & $2 \times 10^{-4}$ \\
n-Pentyl & $10^{-4}$ \\
Iso-pentyl & $10^{-4}$ \\
n-Hexyl & $10^{-4}$ \\
\hline
\end{tabular}

At next, the effect of these compounds and their salts with guanidine was examined by using the system of Mahoney strain and HeLa cells.

Each of dilutions of the tested compounds was added into tubes in which the monosheet of the HeLa cells had been established, and several minutes later, Mahoney strain was inoculated. And then, these tubes were incubated at $37^{\circ}$ for seven days, and in the meanwhile microscopically observed daily. The experimental results are shown in Table 3.

As can be understood from the table, only guanidium $\alpha$-amino- $\gamma$-isopropylthiobutyrate showed a slight effect on the virus among the tested compounds.

* These compounds were synthesized at Pharmaceutical Institute, Keio University. 
Table 3 ,

\begin{tabular}{|c|c|c|c|}
\hline \multirow{2}{*}{$\begin{array}{l}\text { Compound } \\
\text { R-S-CH}-\mathrm{CH}_{2}-\mathrm{CH}\left(\mathrm{NH}_{2}\right) \mathrm{COOH} \\
\mathrm{R} \text { (Mole) }\end{array}$} & \multicolumn{2}{|c|}{ Result $\left(\mathrm{TCID}_{50}\right.$ in $\left.0.1 \mathrm{ml}\right)$} & \multirow{2}{*}{ Effect } \\
\hline & Treated Group & Control Group & \\
\hline No. 1. Isoproply $\left(10^{-3}\right)$ & $10^{-6.5}$ & $10^{-6.5}$ & - \\
\hline No. 2. n-Butly $\left(2 \times 10^{-4}\right)$ & $10^{-6.5}$ & $10^{-6.5}$ & - \\
\hline No. 3. Isobutly $\left(2 \times 10^{-4}\right)$ & $10^{-6.5}$ & $10^{-6.5}$ & - \\
\hline No. 4. n-Pentyl $\left(10^{-4}\right)$ & $10^{-6.5}$ & $10^{-6.5}$ & - \\
\hline No. 5. Isopentyl $\left(10^{-4}\right)$ & $10^{-6.5}$ & $10^{-6.5}$ & - \\
\hline No. 6. n-Hexyl $\left(10^{-4}\right)$ & $10^{-6.5}$ & $10^{-6.5}$ & - \\
\hline Salt of Guanidine and No. $1\left(2 \times 10^{-4}\right)$ & $10^{-6.5}$ & $10^{-8.5}$ & + \\
\hline Salt of Guanidine and No, $2\left(2 \times 10^{-4}\right)$ & $1 C^{-6.5}$ & $10^{-6.5}$ & - \\
\hline Salt of Guanidine and No, $3\left(2 \times 10^{-4}\right)$ & $10^{-6.5}$ & $10^{-6.5}$ & - \\
\hline Salt of Guanidine and No. $4\left(10^{-4}\right)$ & $10^{-6.5}$ & $10^{-6.5}$ & - \\
\hline Salt of Guanidine and No. $5\left(10^{-4}\right)$ & $10^{-6.5}$ & $10^{-6.5}$ & - \\
\hline Salt of Guanidine and No. $6\left(10^{-4}\right)$ & $10^{-8.5}$ & $10^{-6.5}$ & - \\
\hline Guanidine $\left(2 \times 10^{-4}\right)$ & $10^{-6.5}$ & $10^{-6.5}$ & - \\
\hline
\end{tabular}

Table 4.

\begin{tabular}{|c|c|c|c|}
\hline \multirow{2}{*}{ Compound (10-3 Mole) } & \multicolumn{2}{|c|}{ Result $\left(\mathrm{TCID}_{50}\right.$ in $\left.0.1 \mathrm{ml}\right)$} & \multirow{2}{*}{ Effect } \\
\hline & Treated & Control & \\
\hline $\begin{array}{c}\mathrm{NH}_{2}-\mathrm{C}_{\mathrm{NH}}^{\mathrm{NH}} \cdot \mathrm{CH}_{3} \mathrm{COOH} \\
\text { (Guanidine Acetate) }\end{array}$ & $10^{-2.5}$ & $10^{-6.5}$ & + \\
\hline $\begin{array}{r}\mathrm{NH}_{2}-\mathrm{C}_{\mathrm{NH}}^{\mathrm{NH}} \cdot \mathrm{C}_{2} \mathrm{H}_{5} \mathrm{COOH} \\
\text { (Guanidine Propionate) }\end{array}$ & $10^{-2.5}$ & $10^{-6.5}$ & + \\
\hline $\begin{array}{c}\mathrm{NH}_{2}-\mathrm{C}_{N}^{N \mathrm{NH}_{2}} \cdot \mathrm{C}_{3} \mathrm{H}_{7} \mathrm{COOH} \\
\text { (Guanidine Butyrate) }\end{array}$ & $10^{-2.5}$ & $10^{-6.5}$ & + \\
\hline $\begin{array}{l}\mathrm{NH}_{2}-\mathrm{C} / \mathrm{NH}_{2} \cdot \mathrm{CH}_{3}-\mathrm{CH}(\mathrm{OH}) \mathrm{COOH} \\
\text { (Guanidine Lactate) }\end{array}$ & $10^{-2.0}$ & $10^{-6.5}$ & + \\
\hline $\begin{array}{c}\mathrm{NH}_{2}-\mathrm{C} \\
\text { (Guanidine Benzoate) }\end{array}$ & $10^{-2,5}$ & $10^{-6.5}$ & + \\
\hline $\begin{array}{c}\mathrm{NH}_{2}-\mathrm{C}_{\mathrm{NH}_{2}}^{\mathrm{NH}} \cdot\left[\begin{array}{l}\mathrm{CH}_{2} \mathrm{COOH} \\
\mathrm{CH}_{2} \mathrm{COOH}\end{array}\right]_{1 / 2} \\
\text { (Guanidine Succinate) }\end{array}$ & $10^{-3.0}$ & $10^{-6.5}$ & + \\
\hline $\begin{array}{l}\mathrm{NH}_{2}-\mathrm{C}_{N} \mathrm{NH}_{2} \mathrm{HNO}_{3} \\
\text { (Guanidine Nitrate) }\end{array}$ & $10^{-2.0}$ & $10^{-6.5}$ & + \\
\hline
\end{tabular}


3) Inhibitory Effect of Salts of Guanidine and Organic Acids**.

The authors prepared salts of guanidine and several organic acids by reacting guanidine with the acids, to examine as to their effect on Mahoney strain in tissue culture. The experimental procedures were the same to those described above. The experimental results are shown in Table 4.

As shown in the table, these salts were effective in concentration of $10^{-3}$ mole, but any of them ineffective in concentration of $10^{-4}$ mole. This effectiveness is almost equal to that of guanidine nitrate.

\section{DISCUSSION AND CONCLUSION}

As described in the experimental part, the authors examined the antiviral effect of canavanine, norleucine, ethionine and their salts with guanidine in the system of Mahoney strain and HeLa cells, and found that any of the amino acid antagonists was ineffective in its maximum nontoxic concentration on the virus, but guanidium ethionate was effective in a concentration, in which neither guanidine nitrate nor ethionine showed any effect.

That the antagonists were found by the authors to have any antiviral effect with their maximum nontoxic doses, suggests that the effect of the antagonists should be due to the hindrance of the respiration of host cells, but not to the inhibition of the multiplication of the virus. It, therefore, may be said that the antagonists do not any antiviral activity, at least in a concentration less than their nontoxic. This finding is in contrast with that of Ackermann et al, but in accordance with that of Syverton et al.

That guanidium ethionate showed an effect in a concentration, in which both of guanidine nitrate and ethionine did not exert any effect, suggests that the salt is more effective on the virus than guanidine nitrate and that this effect is caused by the potentiation of ethionine on guanidine, but not by the mere synergistic action of guanidine and ethionine. The mechanismus of this potentiation is not possible to make clear at the present state of this study. It is, however, probable that the specific property of ethionine contribute to the inhibition of the intracellular multiplication of the virus, which might be explained from the biological view.

For the comparison, $\alpha$-amino- $\gamma$-alkylthiobutyric acid and its salt with guanidine were synthesized and examined as to their inhibitory effect in Mahoney strain and HeLa cells system. The experimental results showed that only $\alpha$ amino- $\gamma$-isopropylthiobutyrate contributed to the potentiation of guanidine to a very slight extent and all of the other compounds did not affect any influence on the effect of guanidine. This finding suggests that ethionine is the most markedly

** These compounds were synthesized at Pharmaceutical Institute, Keio University. 
potentiating agent among the methionine homologs.

Salts of guanidine with commoner organic acids were also synthesized and examined as to their effects in $10^{-3}$ and $10^{-4}$ mole, using the system of Mahoney strain and HeLa cells. All of the salts were found to have effects almost equal to that of guanidine nitrate in $10^{-3}$ mole, but not any effect in $10^{-4}$ mole. This finding seems to suggest that the salt formation of guanidine with any of commoner organic acid did not contribute to the potentiation of guanidine to any extent, and that the potentiation of guanidine might need a biologically significant amino acid antagonist, such as ethionine.

Recently, J. H. Schneider et al. (4) found that ethionine hindered, in a lower concentartion, the DNA biosynthesis in rat liver homogenate, by the ATP deficiency resulted from the compounding of ATP with ethionine. Since ethionine in a low concentration was found not to inhibit the multiplication of Mahoney strain in tissue culture as described above, the hindrance of the DNA biosynthesis with ethionine might be minorly associated with the inhibition of the viral growth. Probably, the virus might be resynthesized through the DNA biosynthetis by another pathway. On the other hand, Melnick et al.(5) speculated that guanidine might inhibit the multiplication of polio virus by hindering the pathway of the viral nucleoprotein synthesis, in succession of the viral nucleic acid synthesis.

Taking these hypotheses into consideration, it might be speculated that the contribution of ethionine to the potentiation of guanidine might be due to that ethionine partially interfers with the pathway of the viral nucleic acid synthesis, and this effect of ethionine supports the hindering action of guanidine against the pathway of the viral nucleoprotein synthesis.

Works on this line are in progress. The results will be reported in the near future.

\section{SUMMARY}

(1) In order to find more effective agents than guanidine, potentiating agents were searched by means of the salt formation.

(2) The potentiating effect of some amino aicd antagonists was examined, and ethionine was found as the most marked potentiation agent among the antagonists.

(3) The potentiating effect of some of methionine homologs was examined, and any of the homologs was found not to have an effect more significant than ethionine.

(4) The potentiating effect of some of commoner organic acids was ex- 
amined, but any of these acids was found not to show any potentiating effect.

(5) The mechanismus of the potentiation of guanidine with ethionine was speculated, from the hypotheses presented so far.

\section{REFERENCES}

1.a) Ueda, T., Toyoshima, S., Tsuji, T., Seto, Y., and Nomoto, J.: Antiviral effect of guanidine and its derivatives. I. The inhibitory effect of guanidine nitrate on polimyelitis virus. Keio J. Med., 10: 257, 1961.

b) Ueda, T., Toyoshima, S., Tsuji, T., Seto, Y., and Nomoto, J.: The antiviral effect of guanidine and its derivatives. II. The inhibitory effect of guanidine on several virus including measles virus. Antibiotics Chemotherapy, 12: 330, 1962.

2.a) Ackermann, W. W.: The role of L-methionine in virus propagation. J. Exptl. Med., 93: 337, 1961.

b) Ackermann, W. W., Rabsn, A., Kurtz, H.: Growth characteristics of poliomyelitis virus in HeLa cells cultures: Lack of paralleism in cellular injury and virus increase. J. Exptl. Med., 100: 437, 1954.

3. Gifford, G. E., Robertson, H. E., Syverton, J. T.: Application of manometric method to testing chemical agents in vitro for interference with polimyelitis virus synthesis. Proc. Soc. Exptl. Biol. Med., 86: 515, 1954.

4. Schneider, J. H., Cassier, R., and Chorodirian, F.: Inhibition of incorporation of thymidine into deoxyribonucleic acid by amino acid antagonists. J. Biol. Chem., 235: $1437,1960$.

5. Crowther, D., and Melnick, J.: Studies of the inhibitory action of guanidine on poliovirus multiplication in cell cultures. Virology, 15: 65, 1961. 